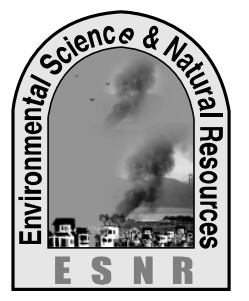

J. Environ. Sci. \& Natural Resources, 6(1): 163 - 166, 2013

ISSN 1999-7361

\title{
Selection of Treatment Process for Textile Dye Wastewater Based on Their Bio-chemical Characteristics
}

\author{
S. Tagar, U. Zakira and F. Ahmed \\ Department of Civil Engineering \\ Bangladesh University of Engineering and Technology, Dhaka-1000, Bangladesh
}

\begin{abstract}
In Bangladesh most of the industries follow chemical treatment process for wastewater treatment without any effluent quality assessment. The aim of this study was to select an effective treatment process for effluent based on its bio-chemical characteristics. Wastewater samples from Textile Industries were collected in 9 batches over a period of 2 months (from17th November, 2011 to 28th April, 2012). Approximately 40liters composite samples were collected of several dying batches from inlet of the equalization tank. Sludge was collected from outlet point of settling tank. The physical, chemical and bio-chemical quality of untreated wastewater were assessed by analyses of some particular parameters in the laboratory and compared with ECR standard. Average concentration of EC $(\mathrm{mS} / \mathrm{cm}), \mathrm{pH}, \mathrm{COD}(\mathrm{mg} / \mathrm{L})$, BOD $(\mathrm{mg} / \mathrm{L})$ and BOD loading $\left(\mathrm{kg} / \mathrm{m}^{3} . \mathrm{d}\right)$ were respectively 3.71, 9.24, 1472, 1024, and 0.205 respectively. For lower BOD loading, the treatment performance was found better..COD decreased rapidly during the first 8 hours of aeration and after 16 hours of aeration it became uniform. During the first $8 \mathrm{hr}$ COD removal was more than $50 \%$ of the initial COD loading. The standard value of COD (200mg/l) was obtained within 12 to 16 hours of aeration for the initial BOD loading less than or equal $0.15 \mathrm{~kg} / \mathrm{m}^{3}$.day and 24 hours of aeration for initial BOD loading 0.16 to $0.26 \mathrm{~kg} / \mathrm{m}^{3}$.day and more than 24 hour for initial BOD loading greater than $0.26 \mathrm{~kg} / \mathrm{m}^{3}$.day. The study revealed that volumetric loading is an important parameter for wastewater which to a great extent sets applicability limit of treatment process. From this laboratory model study, treatment process options have been recommended for industrial effluent having different bio-chemical characteristics.
\end{abstract}

Key Words: Aeration period, Biological treatment, Effluent, Initial COD, Organic BOD loading,

\section{Introduction}

Bangladesh is a developing country and its development is mainly based on industrial development for which expectation of zero polluting industry is just an imagination for Bangladesh. The Ready Made Garment (RMG) Sector in Bangladesh today employs close to 3.5 million workers, a further 10 million people depend on their livelihood because of RMG industry. Due to low labor cost and lower operating cost of Textile industries, they do not take environmental concern as their major concern and the environmental law is very poor for which awareness does not arise. Another reason of reluctance of industry operators and owners to maintain an effluent treatment plant is the operating cost. Industry owners of a least developing country (LDC) like Bangladesh are often reluctant to allocate their budget for effluent treatment because the options for treating textile wastewater are very expensive.

For this reason, the industries discharge these wastes into surface water course without proper treatment by by-passing the law. So, choosing appropriate and cost effective treatment option is one of the major steps toward reducing pollution from textile industries. So, in this study we have conducted wide investigation to analyze the characteristics of textile wastewater and proper cost effective treatment methods have been suggested for discharging textile wastewater into surface water body with compliance to Bangladesh Environmental Quality Standard (1997).

The principal objective of wastewater treatment is generally to allow industrial effluents to be disposed of without danger to human health or unacceptable damage to the natural environment. The most appropriate wastewater treatment to be applied before effluent disposal to water bodies is that which will produce an effluent meeting the recommended microbiological and chemical quality guidelines both at low cost and with minimal operational and maintenance requirements. In this regard, Sharminand Paul (2012) has studied on wastewater treatment of Textile Industries. In their study they did not recommend the effluent treatment options depending on effluent quality, i.e, COD, volumetric loading of raw effluent. Moreover, they did not study on wastewater having variation in quality. So, selection of treatment process investigating water quality assessment needs to be done. With this background in mind, the present work was designed to investigate the wastewater characteristics in the laboratory model study and to select effective treatment option for textile wastewater.

\section{Materials and Methods}

\section{Sampling Site}

The quality of textile wastewater varies greatly in composition depending on the type of the cloth is to 
be processed, the type of dye used and the variation in the process regarding yarn treatment. Considering these facts, preparation of a synthetic sample for study of the efficiency of removal was not rational. Therefore, we had to collect the water from EOS Textile Industry, located on Dhaka Export Processing Zone (DEPZ) that is already in production. The EOS Textile Industry generates wastewater from dyeing plant and treatsit in an effluent treatment plant (ETP).

\section{Sample Collection}

Samples were collected in 9 batches over a period of 2 months (from17th November, 2011 to 28th April, 2012). Approximately 40 liters composite samples were collected of several dying batches from inlet of the equalization tank. Sludge has been collected from outlet point of settling tank.

\section{Biological Treatment Process}

Biological processes were used extensively in wastewater treatment process to convert biodegradable organics and other nutrients into a more manageable form. Conditions which must be fullfilled to carry out biological process were following- Allowable $\mathrm{pH}$ was in the ranges between

\section{Results and Discussion}

The results obtained on physical, chemical and biochemical quality of untreated wastewater assessed by

Table 1: Variation of wastewater characteristics
6-9, temperature within $25-30^{\circ} \mathrm{C}$, nutrients for increasing microorganism activities and absence of toxic substances. With activated sludge treatment, the removal performance depends on initial BOD loading. Generally for sequential batch process BOD loading limit was $0.1-0.3 \mathrm{~kg} / \mathrm{m}^{3} /$ day.

\section{Biological Treatment Setup}

At first, pH, EC, Color and COD of raw samples were measured. Raw samples were adjusted to $\mathrm{pH} 7$ with sulphuric acid solution. Adjusted sample was added to 1 liter sludge in such amount so that 4 liter wastewater sample was prepared. Then aeration was done by diffuser. After certain period of time, diffuser was turned off and sample was collected after $30 \mathrm{~min}$ settling time. EC, $\mathrm{pH}$, Color, COD of collected samples were measured. Rest of water was removed by water pressure from the raw sample. The entire process was repeated for different concentration of organism. In such way, due to the acclimatization of bacterial population with environment of the aeration basin, efficiency of COD and BOD removal was increased gradually.

analyses of some particular parameters in the laboratory and compared with ECR standard are presented in Table 1.

\begin{tabular}{|c|c|c|c|c|c|}
\hline \multirow{2}{*}{ Type of qualities } & \multirow{2}{*}{$\begin{array}{l}\text { Wastewater quality } \\
\text { parameters }\end{array}$} & \multicolumn{2}{|c|}{ Concentration range } & \multirow{2}{*}{$\begin{array}{c}\text { Average } \\
\text { concentration }\end{array}$} & \multirow{2}{*}{$\begin{array}{c}\text { ECR } \\
(1997)\end{array}$} \\
\hline & & Maximum & Minimum & & \\
\hline \multirow{2}{*}{ Chemical } & $\mathrm{EC}(\mathrm{mS} / \mathrm{cm})$ & 5.48 & 2.32 & 3.71 & 1.2 \\
\hline & $\mathrm{pH}$ & 11.02 & 7.98 & 9.24 & $6-9$ \\
\hline \multirow{3}{*}{ Bio-chemical } & $\mathrm{COD}(\mathrm{mg} / \mathrm{L})$ & 2390 & 810 & 1472 & 200 \\
\hline & $\mathrm{BOD}(\mathrm{mg} / \mathrm{L})$ & 1365 & 679 & 1024 & 50 \\
\hline & BOD Loading $\left(\mathrm{kg} / \mathrm{m}^{3} . \mathrm{d}\right)$ & 0.273 & 0.136 & 0.205 & - \\
\hline
\end{tabular}

Table 1 shows that raw wastewater contains more bio-degradable portion. The COD: BOD ratio results in greater volumetric loading, referring to standard BOD loading limit of Sequencing Batch reactor process $0.1-0.3 \mathrm{~kg} / \mathrm{m}^{3}$.day (Metcalf and Eddy, 2003). But according to the Environment Conservation Rule (1997), effluent COD and BOD $_{5}$ must be within 200 $\mathrm{mg} / \mathrm{l}$ and $50 \mathrm{mg} / \mathrm{l}$ respectively. So, it was very imperative to select a particular treatment option which will be effective to treat wastewater having such high BOD loading.

\section{Effect of Volumetric loading}

The volumetric BOD loading in the aeration tank is one of the points that should be considered with great concern. From laboratory studies it has been found that for lower BOD loading, the BOD removal performance decreased when other conditions remained same. It can be explained using fundamental concept of BOD kinetics, which states that biodegradation rate depends on the total BOD remaining in wastewater. On the other hand, in presence of excessive BOD loading the treatment process may turn practically into anaerobic system. Effect of BOD loading can be demonstrated by predominant characteristics of initial COD value of sample on the removal performance. 
Effect on Initial COD range between $800-1000 \mathrm{mg} / \mathrm{l}$ The variation of COD value with aeration period for three samples, which had their initial COD within $800-1000 \mathrm{mg} / \mathrm{l}$, can be understood from following figure. From Figure1, it is found that COD decreased rapidly during the first 8 hours of aeration and after 16 hours of aeration it became uniform. During the first $8 \mathrm{hr}$ COD removal was more than $50 \%$ of the initial COD loading.

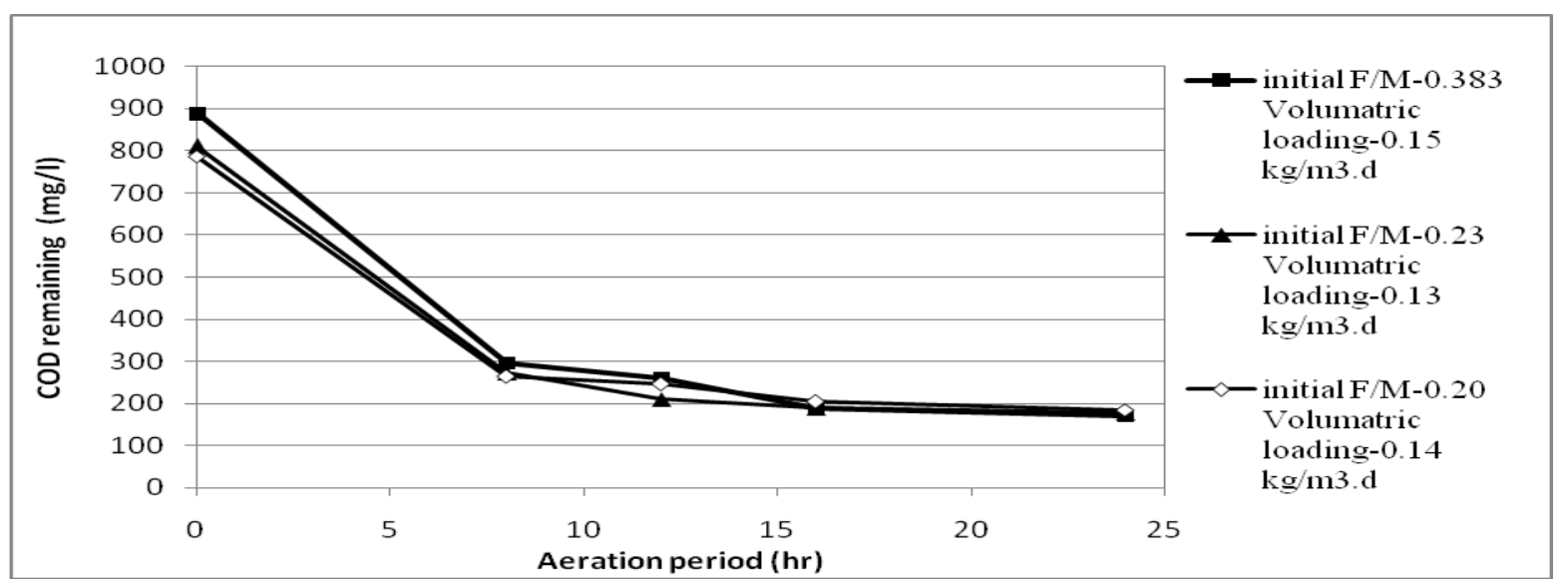

Figure 1: Comparison of COD remaining with aeration period between similar batches

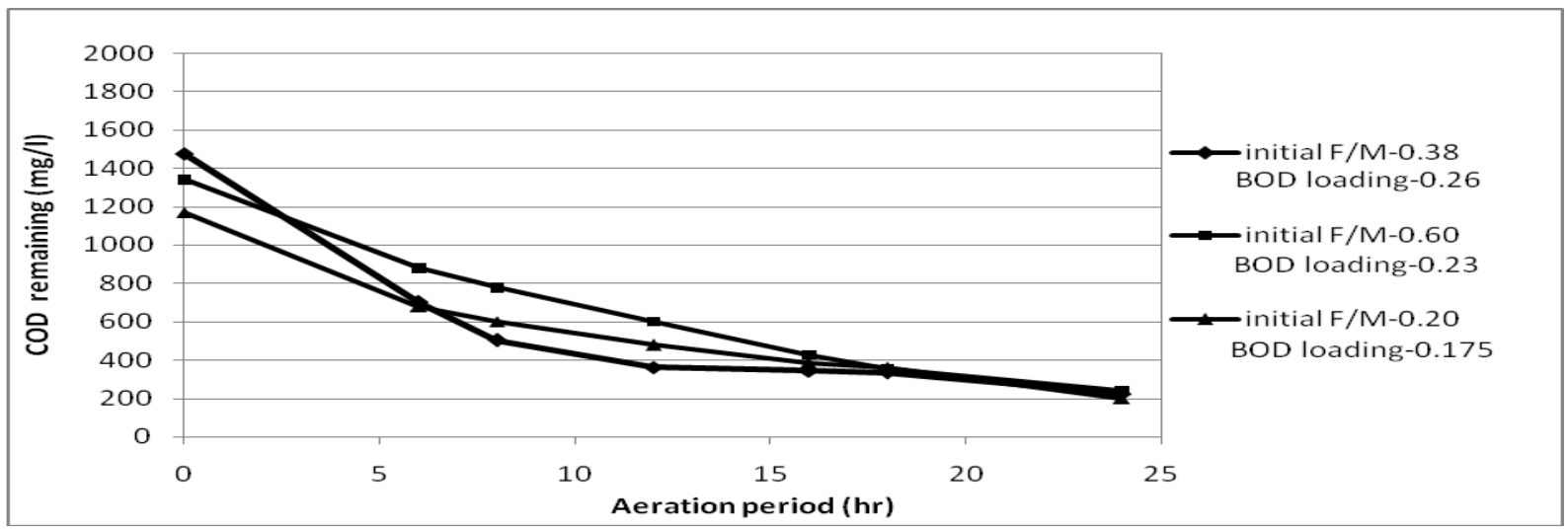

Figure2: Change in COD remaining with aeration period for different batches

The curve also reveals that the standard value of COD $(200 \mathrm{mg} / \mathrm{l})$ was obtained within 12 hours of aeration for the initial BOD loading $0.13 \mathrm{~kg} / \mathrm{m}^{3}$.day and 16 hour of aeration for both initial BOD loading 0.14 and $0.15 \mathrm{~kg} / \mathrm{m}^{3}$.day.

\section{Effect on Initial COD range between 1000-1500 $m g / l$}

Change in COD value with aeration period for samples having initial COD value within 1000-1500 $\mathrm{mg} / \mathrm{l}$, is shown in Figure 2. From figure it is found that initial COD value decreased rapidly during the first 8 hours of aeration and then it became uniform. For the first 6 hour there was no significant change in COD value for initial BOD loading 0.175 and 0.23 $\mathrm{kg} / \mathrm{m}^{3}$.day, whereas a drastic removal of COD was observed for initial BOD loading $0.26 \mathrm{~kg} / \mathrm{m}^{3}$.day.This may be due to proper acclimatization of biomass of the latter one.

From the figure it is observed that, allowable COD cannot be achieved before 24 hours. This is because of their high volumetric loading (greater than $0.16 \mathrm{~kg}$ $\mathrm{BOD} / \mathrm{m}^{3}$.d).In this case aeration period can be reduced through biological treatment prior to chemical treatment process.

\section{Effect on Initial COD value greater than $1500 \mathrm{mg} / \mathrm{l}$}

Higher COD value indicates high organic pollution. From Figure 3 , it is seen that 24 hours aeration failed to comply with the standard of $200 \mathrm{mg} / \mathrm{l}$. This is because of high volumetric loading of sample which is $0.273 \mathrm{~kg} \mathrm{BOD} / \mathrm{m}^{3} . \mathrm{d}$ (close to $0.3 \mathrm{~kg}$ 
$\mathrm{BOD} / \mathrm{m}^{3}$.d).Treatment plant would fail if influent $\quad$ COD is close to $2000 \mathrm{mg} / \mathrm{l}$.

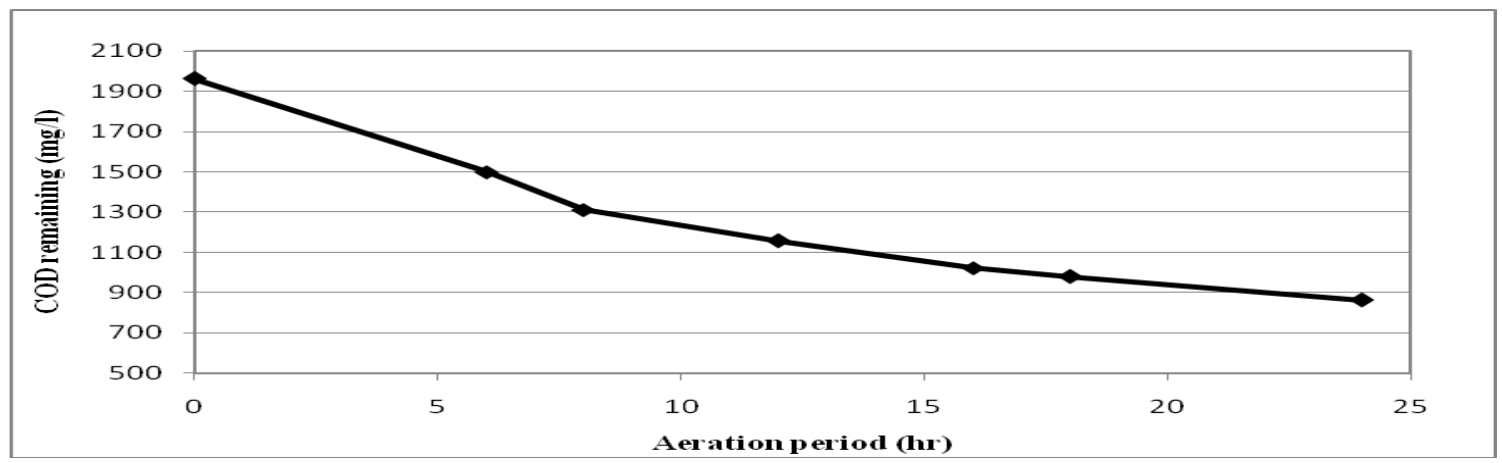

Fig.3: Change in COD remaining with aeration period

In this case separate treatment, biological treatment prior to chemical treatment or dilution process may be the most probable solutions from laboratory model studies it is found that Biological treatment can be used extensively for treatment of wastewater having low levels of biodegradable organics (BOD loading less than $0.15 \mathrm{~kg} / \mathrm{m}^{3}$.day). For initial BOD loading range $0.16-0.26 \mathrm{~kg} / \mathrm{m}^{3}$.day, biological treatment prior chemical to treatment significantly reduces both aeration period and chemical cost. For Initial BOD loading above $0.26 \mathrm{~kg} / \mathrm{m}^{3}$.day, probable solutions could be chemical treatment prior to biological treatment process or dilution ahead of biological process of wastewater. Therefore, the following recommendations (Table 2) can be forwarded based on the findings of the present study.

Table 2: Recommendations based on Volumetric Loading of raw wastewater

\begin{tabular}{|l|c|c|}
\hline \multicolumn{1}{|c|}{ Recommended Treatment Process } & Initial COD(mg/l) & $\begin{array}{c}\text { Initial BOD Loading } \\
\left(\mathbf{k g} / \mathbf{m}^{\mathbf{3}} \mathbf{. d}\right)\end{array}$ \\
\hline Biological Treatment & $<1000$ & $\leq 0.15$ \\
\hline Biological Treatment prior to Chemical Treatment & $1000-1500$ & $0.16-0.26$ \\
\hline $\begin{array}{l}\text { Dilution prior to Biological Treatment/Chemical } \\
\text { Treatment prior to Biological Treatment }\end{array}$ & $>1500$ & $>0.26$ \\
\hline
\end{tabular}

\section{Conclusion}

Currently, the textile dyeing wastewater is one of the most important sources of pollution. This type of wastewater has the characteristics of higher value of color, BOD and COD, complex composition, large emission, widely distributed and difficult degradation. If being directly discharged without being treated, it will bring serious harm to the ecological environment. Therefore, the goal of wastewater treatment is to remove as much of the floating and biodegradable pollutants and disease-causing agents in wastewater as possible to minimize the risks to public health and impact on the environment.

\section{References}

Gray, N. F. 1989. Biology of Wastewater Treatment. Oxford University Press, USA, pp.72-77, 340-343

Mara, D. Duncan, 1976. Sewage Treatment in Hot Climates. A Wiley-Inter Science Publication, London.
Metcalf and Eddy. 2003. Wastewater Engineering Treatment and Reuse. $4^{\text {th }}$ edition, Tata McGraw Hill Publishing Company Limited, New Delhi, pp.747

The Environmental Conservation Rules.1997. The Department of Environment, Bangladesh.

Marcos Von Sperling, Carlos Augustos de Lemos Chernicharo.2005. Biological Wastewater Treatment in Warm Climate Regions, Volume 1,pp 542

Peavy; Rown and Tchobanoglous.1985. Environmental Engineering. McGraw-Hill International Editions.

Sharmin; Afia; Paul and Manashi. 2012. Wastewater Treatment of Textile Industries. MS Thesis, Department of Civil Engineering, Bangladesh University of Engineering and Technology, March, 2012, pp 74. 